\title{
Temanummerets forord
}

\author{
PETER B. ANDERSEN, BRIAN ARLY JACOBSEN, LENE KÜHLE, HENRIK \\ REINTOFT CHRISTENSEN, HEIDI FRØLUND PEDERSEN, HANNE \\ WÜRTZEN, PETER LA COUR \& JESPER F. SØRENSEN
}

Forskningen bag dette temanummer COVID-19 - Religion, trivsel og eksistens blev muliggjort af en akutbevilling til dataindsamling vedrørende COVID-19-krisen fra VELUX FONDEN. Fra vi modtog bevillingen, gik der kun få uger, før vi gennemførte en elektronisk spørgeskemaundersøgelse i slutningen af nedlukningsperioden i foråret 2020. Det er data fra dette spørgeskema, der er kernen i nærværende temanummer COVID-19 - Religion, Trivsel og Eksistens. Men temanummeret indeholder endvidere en række artikler, der udforsker undersøgelsens kontekst. Med afsæt i formodningen om, at erindringerne om detaljerne vedrørende nedlukningen mellem den 11. marts 2020 og frem til den begyndende genåbning i maj samme år løbende vil fortone sig, og med ønsket om at tilbyde ikke mindst læsere, der måtte gribe ud efter nummeret om en årrække, en hjælpende oversigt, har vi forsynet nummeret med en redegørelse for forløbet fra marts til oktober 2020 samt en grafisk opsummering i kraft af en tidlinje. Begge dele findes i nummerets første artikel "COVID-19-krisen: Forløb og bekymringer" af Peter B. Andersen, Brian A. Jacobsen, Lene Kühle, Henrik Reintoft Christensen, Heidi Frølund Pedersen, Hanne Würtzen, Peter la Cour \& Jesper F. Sørensen.

Da pandemien kom til Danmark, var der kun få, der havde personlige erfaringer med COVID-19. Reaktionerne på sygdommen var derfor i meget høj grad relaterede til de oplysninger, som befolkningen fik gennem medierne. Vi har derfor kortlagt pressens dækning af forløbet i nummerets anden artikel "Befolkningens reaktion på COVID-19 set i lyset af aviser og andre medier" af Peter B. Andersen, Awiti Luna Tengu Nyawade Høeg, Henrik Reintoft Christensen, Brian A. Jacobsen, Lene Kühle og Peter la Cour.

I religionsvidenskabelig og psykologisk forskning har man ofte tillagt truslen om død og lidelse stor betydning. I visse teorier opfattes døden endog som selve grundlaget for fænomenet religion. Eftersom den danske regerings nedlukningsbeslutning blev begrundet med statsminister Mette Frederiksens konstatering: "hvert eneste dødsfald er en tragedie", opfatter vi det som naturligt og relevant at dedikere en af temanummerets artikler til en oversigt over sådanne teorier. Disse finder man i nummerets tredje artikel, "Historiske og teoretiske baggrunde for COVID-19-pandemiens påvirkning af den danske befolkning" af Jesper F. Sørensen, Katrine F. Baunvig, Heidi 
F. Petersen, Brian A. Jacobsen, Lene Kühle og Peter B. Andersen, der endvidere skitserer den udvikling i døds- og efterlivsforestillinger, som er fundet sted i nyere tid i Danmark.

I tillæg til og med afsæt i de tre første, oversigtdannende og kontekstualiserende artikler følger rækken af analytisk-udforskende artikler. Nummerets fjerde artikel "COVID-19 og religion" af Henrik Reintoft Christensen, Lene Kühle og Brian A. Jacobsen undersøger således, hvorvidt den danske befolkning kan siges at være blevet mere religiøs under krisen. Nummerets femte artikel, "Helbred og trivsel" af Peter la Cour og Heidi Frølund Pedersen, afdækker, hvorledes befolkningens almene psykiske velvære har været under pres i perioden. Nummerets sjette artikel angår, som titlen "Livsmening, krise og optimisme under COVID-19" af Heidi Frølund Pedersen og Peter la Cour antyder, sammenhængene mellem grader af oplevet meningstab, eksistentiel krise og religion i befolkningen. Artikel fem og seks bryder således med dette tidskrifts tematiske ramme, men er af interesse for nummerets overordnede undersøgelseshorisont. Nummerets syvende artikel, "Mellem fællessang og håndvask. Ritualer og COVID-19" af Jesper F. Sørensen, Katrine F. Baunvig og Peter B. Andersen, undersøger pandemiens påvirkning af befolkningens rituelle adfærd. Endelig bliver den generelle tillid i samfundet og tilliden til myndighederne i forhold til politisk tilhørsforhold og forskellige former for religion behandlet i nummerets ottende artikel "Tillid til andre og den sekulære velfærdsstat" af Brian A. Jacobsen, Henrik Reintoft Christensen og Lene Kühle. Disse forskellige analyser muliggør tilsammen en opsamling i den afsluttende "Konklusion" af Lene Kühle og Peter B. Andersen.

Selvom temanummeret således sigter på en samlet analytisk konklusion, har vi søgt at skrive de enkelte artikler, så det er muligt at læse dem enkeltvis. Vi har også bestræbt os på brug af letafkodelige grafer frem for tabeller som visualisering. På visse punkter har dette imidlertid ikke være muligt og/eller hensigtsmæssigt; tilsvarende har angivelsen af statistiske mål (korrellationer, signifikanser) undertiden været formålstjenstlige at angive. De væsentlige metodeoplysninger har vi endvidere beskrevet i nummerets "Appendiks".

Peter B. Andersen, lektor, ph.d. Religionsvidenskab, Københavns Universitet

Henrik Reintoft Christensen, lektor, ph.d. Religionsvidenskab, Aarhus Universitet

Brian Arly Jacobsen, lektor, ph.d. Religionsvidenskab, Københavns Universitet

Lene Kühle, professor mso, ph.d. Religionsvidenskab, Aarhus Universitet 
Peter la Cour, lektor, ph.d.

Institut for psykologi, Københavns Universitet

Heidi Frølund Pedersen, seniorforsker, ph.d. Funktionelle Lidelser, Aarhus Universitetshospital

Jesper F. Sørensen, lektor, ph.d. Religionsvidenskab, Aarhus Universitet

Hanne Würtzen, klinisk psykolog, ph.d. Tværfagligt Smertecenter, Rigshospitalet

\section{Tak}

Dette temanummer er den første forskningspublikation fra projektet "COVID-19 Religion og eksistens". En stor tak til VELUX FONDENs COVID-19 initiativ som med en bevilling til projektet "COVID-19 - Religion og eksistens" har muliggjort indsamlingen af surveyet bag temanummeret og har støttet udgivelsen. Vi vil også gerne sige tak til de øvrige projekter under VELUX FONDENs COVID-19-intiativ for inspiration og interaktion. I tillæg ønsker vi at rette en varm tak til Danmarks Frie Forskningsfond, der med sit Corona-call og bevilling af midler til Katrine Frøkjær Baunvigs forskningsprojekt "Fællessang - hver for sig. Virtuelle ritualer i en krisetid" understøttede tilblivelsen af dette nummer. Endelig skal vi rette en stor tak til vores respektive arbejdspladser for med kort varsel og i konflikt med eksisterende planer for vores opgaver at skyde den nødvendige arbejdstid i projektet. 